\title{
Social Entrepreneur Responsibility: Contradiction and Reasons
}

\footnotetext{
Submitted 06/06/20, 1st revision 11/07/20, 2nd revision 14/08/20, accepted 15/09/20

Makarenko Elena ${ }^{1}$, Chernysheva Yulia ${ }^{2}$, Polyakova Irina ${ }^{3}$, Shepelenko Gariy $^{4}$, Kislaya Irina ${ }^{5}$, Makarenko Tatiana ${ }^{6}$

\section{Abstract:}

Purpose: Social responsibility of business and entrepreneur is relatively new notion that is getting more relevant nowadays. This notion is considered from different views and aspects. The problem of social responsibility is most acute in small businesses. Why should an entrepreneur be socially responsible, who is interested and why? To understand social responsibility, it is necessary to study these and other issues of social responsibility.

Design/Methodology/Approach: The article examines, identifies, and generalizes main factors of social responsibility in Russia and abroad. The authors use the system of tools and methods of economic analysis, consider qualitative and quantitative characteristics and features of social responsibility category both in general regarding business and to a small business.

Findings: As a result, the authors determine that the category of social responsibility of the entrepreneur should be viewed from the point of view of the system of contradictions between the owner-entrepreneur and the employees.

Practical Implications: The results of the study could be used for practical purposes. An entrepreneur can develop a system of measures to increase his level of social responsibility towards employees, thereby alleviating the perceived contradiction, which will ultimately strengthen the success of his business.

Originality/Value: The authors' position is because today business is finding it increasingly difficult to compete. Improving the social responsibility of the entrepreneur is one of the factors that increase the competitive advantage of the enterprise, the loyalty of the employees by reducing social tension.
}

Keywords: Social responsibility, small business, socio-economic contradiction.

JEL code: $M 21$.

Paper type: Research article

${ }^{1}$ PhD in Economics, Associate Professor, Rector of Rostov State University of Economics (RINH), Rostov-on-Don, Russian Federation.

${ }^{2}$ Corresponding author, PhD in Economics, Professor of Rostov State University of

Economics (RINH), Rostov-on-Don, Russian Federation, julia282001@mail.ru

${ }^{3}$ PhD in Economics, Professor of Rostov State University of Economics (RINH), Rostov-on-

Don Russian Federation, mirgan15@mail.ru

${ }^{4}$ Same as in 3.

${ }^{5}$ PhD in Economics, Docent of Rostov State University of Economics (RINH), Rostov-onDon, Russian Federation.

${ }^{6}$ Senior Tutor of Rostov state university of economics (RINH), Rostov-on-Don, Russian Federation. 


\section{Introduction}

The notion of social business responsibility is a relatively new concept that is currently gaining an importance. A significant number of publications are devoted to this area. The social responsibility of entrepreneurship is examined from different perspectives. The International Standard ISO 26000 "Guidance on social responsibility" was introduced in 2010 that provides the generalized definition of social responsibility as "the responsibility of a business for its decision and activities to society and the environment through transparent and ethical behaviour, which pursues a number of objectives:

-promotes sustainable development, including public health and welfare;

- takes into account the expectations of stakeholders;

- complies with international standards of conduct and legislation, both international and national;

• introduced in the whole organization"'.

However, the scientific literature still lacks a single concept of the social responsibility of business. According to this standard, the social responsibility of business reflects the nature of the behaviour of both the society as a whole and an organization for its sustainable development. Business should create conditions conducive to improving the living standards of all stakeholders: the company, shareholders, partners, employees. Social business responsibility can be considered from different points of view, for example, as the involvement of the business in social events, the activities of social nature. There is one more aspect of social responsibility, i.e. relationship between the owner-entrepreneur and employees. The reasons for the differences between their interests have not been studied carefully yet. To identify the reasons for this difference we can use such driving force of the development as contradiction. It is possible to put forward a hypothesis: in the modern economy, there was a contradiction between the interests of the entrepreneur and hired workers due to the difference in their attitude towards organizing the production process at the enterprise. This contradiction has led to deteriorating the problem of social business responsibility that makes it necessary to look for the ways of its solution.

There are three main interested parties in forming the social responsibility of the entrepreneur and mitigating this contradiction: entrepreneurs - owners of the business, employees, and the state. Each will benefit from mitigating this contradiction. Employees will have better conditions and reward for their work, for the state - this is one of the factors to ensure the stable socio-economic environment in the society, for enterprises - it is the opportunity to receive extra benefits: forming, keeping and attracting more qualified employees, the growth of productivity.

${ }^{7}$ International standard ISO 26000 «Guidance on social responsibility» 
It can be said that today the social responsibility of business is a multi-level category. It reflects the relationship between society and business, which relates to the identification and resolution of conflicts between their interests. This makes it possible to increase the efficiency of the business, orient it towards increasing the welfare and expectations of various stakeholders such as shareholders, employees.

In terms of different categories of enterprises, experience has shown that greater social responsibility is inherent in large and medium-sized enterprises. Small business represents a special socio-economic segment with more contentious issues, including social responsibility.

One can say that the problem of social entrepreneurship responsibility is one of the most crucial problems that can hinder small business development. The social responsibility of small business (entrepreneurship) is a specific decision-making process that considers the socio-economic consequences of entrepreneurial activity based on respect for employees and consumers. Therefore, the study of the problems of social responsibility of small businesses is, in our view, of considerable interest. By increasing socio-environmental responsibility of entrepreneurs, one can solve several socio-economic problems since the state, the public and an entrepreneur himself are interested in it.

\section{Historical Aspects of the Emergence, Characteristics and Problems of Social Responsibility of Business}

Abroad, the concept of corporate social responsibility began to take shape in the XX century. This was based on the theories of M. Friedman (1962). The concept is based on monetarism. One of his provisions is an understanding of the special role of the state and its impact on the economic and social system of the society based on money turnover.

Thus, entrepreneurs have a constant desire to reduce the uncertainty in achieving the «social quality» of their product, as well as the propensity of business to take risks in the search for mechanisms allowing to produce products of the «social quality» required by society. This means that social responsibility becomes a factor of business efficiency.

The concept of corporate social responsibility was also influenced by the theories of Rawls (1999) and Nozick (1974) on social justice. Rawls developed a theory of equity, according to which people are interested in increasing their share of the benefit and thereby reducing the overall benefit.

For instance, the United States, influenced by ethno cultural specifics, has developed independent models of corporate social responsibility because corporations themselves have initiated socially responsible activities. In this way, they determined their own social contribution. In Europe, the system of social responsibility of 
business is based on state regulation, the constitutional institutionalization of the public law system, which enshrines the primacy of the common good of the people.

Thus, one can say that in the economies of developed countries the concepts 'social activity' and 'business responsibility' began to emerge gradually from almost unrelated standards of environmental and labor protection, aspects of entrepreneurial activity related to social issues. Furthermore, one of the factors, that influenced this, was the need to find new decisions in organizing the work that allows to increase the productivity based on the improvement of social conditions.

Most concepts of corporate social responsibility are economic. However, some of them are more social and based on the concept of the common good and equity. These models focus specifically on the social component of the responsibility of entrepreneurship. Such models consider the social responsibility of business as a social, rather than an economic, aspect corresponding to the rights of the state and the population.

This aspect is expressed in the reproduction of the human being as an expensive labour force in an organization in the physical sense, and as a subject of some social group. These concepts consider business as a part of a system of social reproduction, reproduction of life, race. In these concepts, business efficiency is assessed based on the human development index, the intellectual capital of the labour force and the population at the place where the business was established. This view of the social responsibility of business enables to involve the business in the processes of socialization and social control.

The social responsibility of the entrepreneur is, for sure, not limited to charity. The content of social responsibility has evolved simultaneously with the evolution of social consciousness and the re-evaluation of values by society. Speaking about the social responsibility of entrepreneurship, it is also necessary to assess the business reputation, as it will also reflect the social responsibility of the firm.

In Russia, the system of social responsibility of business has its own specific features. There is a widespread lack of respect for socially responsible behaviour, especially by small businesses. This is often due to the narrower range of stakeholders whose views should be considered in this regard. In addition, the interests of employees working in small business are less protected, as there are usually no trade unions in small enterprises. As a result, the rights of small business workers are frequently violated, and they lack social benefits and other social guarantees.

It can be said that the level of social responsibility also depends on the social expectations of the people, at a certain period of development of the society, the country, and the relations of morality. For example, the most obvious problems of social responsibility begin to manifest themselves in transitional periods, when strikes, protests and business ethics among entrepreneurs are frequent. All these 
aspects should be considered by business leaders when choosing to solve problems related to the social responsibility of business. To solve them it is necessary to change managers' social settings, social management methods, to create more favourable working conditions thereby increasing social responsibility of business.

Nowadays there is a tendency towards the transition of Russian economy from the economy in which the main purpose of entrepreneurs was to get profit despite existing contradictions between labour and capital to socially-oriented economy characterized by improving social economic conditions of the activity for employees which makes it possible to use their social and personal reserves at work.

As noted, the social responsibility of entrepreneurship is currently treated differently. We believe that it should include responsibility for fulfilling social obligations to the staff: the provision of a social package, labour safety, prohibition of child labour, the provision of additional social bonuses. Ensuring the social responsibility of entrepreneurship will allow the organization to maintain its economic sustainability and increase the efficiency of activities by using the so-called social reserve.

The social package for employees contains both direct and indirect benefits. Direct benefits include material benefits such as incentive payments, interest, bonuses, etc. and moral benefits such as letters, commendations, status upgrades. Indirect benefits may be corporate - corporate mobile phone, transport, food, medical care, discounts on own goods, etc.; public - payment of sick leave, holidays etc.

The development of market economy makes it necessary to search for new reserves able to increase the efficiency of business. As a result, the use of social reserve is a progressive direction since the social responsibility of the entrepreneur is beneficial to him due to the fact that employees wok in socially comfortable environment that positively influences both the performance and workers with social security system.

Three main stakeholders can be identified in the formation of socially responsible entrepreneurship: business owners - entrepreneurs, employees, and the state.

The interest of small business employees is in the fact that they are almost unable to claim their social rights on their own and to receive additional social privilege since there are no labour unions at small enterprises because in Russia more than $95 \%$ of small businesses are microenterprises.

The state is interested because it is one of the factors for creating and ensuring a stable social and economic environment in society, as well as an opportunity to create a positive business environment.

Although there is a great deal of interest in promoting socially responsible entrepreneurship, there are some difficulties and problems in implementing this in practice. For example, entrepreneurs face the challenge of becoming socially 
responsible because they are reluctant to do so. On the one hand, some entrepreneurs are already aware that the development of social responsibility is a worldwide trend and that they value their reputation. They understand that increasing their commitment to society as a whole and to their workforce is beneficial to entrepreneurship. Organizations that have a policy of prioritizing the social protection of their workers have developed a better reputation among the population than others. These policies provide them with some benefits: forming, keeping and attracting more qualified staff that makes it possible to reduce costs on the staff development, in addition, it helps not to suffer losses of efficiency in firing and hiring new employees that involves the decrease in efficiency. With more qualified workers, an enterprise can produce better products, which creates consumer confidence in the products, works and services of the enterprise. Such advantages, due to the different times of their effectiveness for business, are not immediately apparent, but the effect will still occur. This is borne out by the experience of foreign countries that have already done so.

Nevertheless, a large number of organizations still do not want to realize the necessity of moving from «business as a means of income» to the category of «socially responsible entrepreneurs». The state can enhance this process by providing incentives to entrepreneurs who implement various social programmes. In our view, this is one of the main ways to increase the number of socially responsible entrepreneurs. That is, the enterprise receives additional economic benefits from the state if it implements social programmes. This public policy to promote socially responsible entrepreneurship should be of a long-term nature. In addition, the state may promote or organize regional events, such as fairs for social projects, competitions in which enterprises can obtain grants for the implementation of social programmes.

Abroad, research has identified key indicators that can measure the economic impact that entrepreneurs, who are socially active and who implement social programmes, can have: rate of return on charitable investments: measure of the effectiveness of a charitable program compared to other noncharitable funds (advertising, sales promotion programs) (Weiser and Zadek, 2000). Scientists have also developed methods for estimating social entrepreneurship programmes: the triple account method - creating stability of the business environment; the balanced scorecard method - capitalization and financial policy, complex of marketing; method of calculation of the index of corporate charity - expansion of innovations contributing to the expansion of the market and other (Shevchuk, 2005).

The studies have shown that social factors influence the main techno-economic indicators of entrepreneurial activity. There is a correlation between social responsibility, reputation, and loyalty to the firm: active social and charitable policies - increased trust of employees, shareholders, and other stakeholders; improving reputation - increasing business performance, especially capitalization (Ivchenko, 2003). 
No significant studies have been conducted in Russia on the relationship between the social responsibility of the entrepreneur and the sustainable development of the organization. One likely reason for this is the underestimation and lack of understanding, particularly on the part of entrepreneurs, of the importance of social business programmes for the effective development of entrepreneurship. This can be one of the reasons for the fact that in our country social responsibility of entrepreneurs is not widespread, and a great number of entrepreneurs do not consider employees' interest in the results of their work as a component of successful development of an enterprise.

In addition, the low proportion of socially responsible entrepreneurs can be attributed to the situation on the labour market and violations of labour legislation by the employer. The unfavourable situation in the labour market is due to high unemployment, inflation, and legally illiterate workers. All this gives advantage to employers, resulting in «unofficial» relations between the employee and his employer. Thus, conflict resolution and the hiring and firing of workers are currently not regulated by the state, but by private agreements between the worker and the employer.

Most cases of non-compliance with labour legislation are because small enterprises generally do not have lawyers, personnel specialists or trade unions. Therefore, workers' rights are often violated, including due to their unawareness of legislation. This may result in the absence of payment for overtime work, work on weekends, employment of underage children without reduced working hours, etc. There may also be a discrepancy between the actual wages received and those processed.

\section{Analysis of the Social Responsibility of the Entrepreneur through a System of Contradictions}

As noted, the concept of social responsibility is studied enough. Nevertheless, we believe that one should differentiate various social business responsibilities. First, the social business responsibility can be expressed in participation in social projects, conducting other social activities, providing social charitable assistance, etc. Secondly, the social business responsibility can include compliance with environmental norms, the production of environmentally friendly products, which is respect for people and, consequently, increases customer loyalty. A lot of publications are devoted to these two aspects and their influence on business success has already been well studied

However, in our opinion, there is such an aspect of social responsibility as the social responsibility of the owner-entrepreneur of a small enterprise in relation to his employees, which nature has been studied little. We believe this aspect of social responsibility to be typical for any business, but it affects small business more seriously due to the nature of closer relationship between a business owner and his employees. As a rule, the conflicts between the interests of the owner-entrepreneur 
and the employees are generally viewed from the point of the conflict between the interests of the employee and the employer, and between current economic interests or interpersonal working interests. However, the cause of their conflict of interest lay somewhat deeper and touched upon the philosophical category of contradictions.

This responsibility stands for not only the compliance of the labour legislation but also socio-economic relations that develop between them. As is known the interests of an owner-entrepreneur and employees are different. They have different attitudes toward the organization of production activities at a small enterprise, fixed assets, motivation and work content, social guarantees. The difference in their interests emerges in many aspects of business performance (Table 1).

Table 1. Peculiarities of employees' interests and owner-entrepreneur's interest in small business

\begin{tabular}{|l|l|l|}
\hline \multicolumn{1}{|c|}{ Factors } & \multicolumn{1}{|c|}{ Employee's interests } & \multicolumn{1}{|c|}{ Owner-entrepreneur's interests } \\
\hline Attitude towards risk & Avoid or minimize & $\begin{array}{l}\text { Use to receive more income, even at } \\
\text { the cost of employees }\end{array}$ \\
\hline $\begin{array}{l}\text { Attitude towards means of } \\
\text { production }\end{array}$ & facilitate their work & $\begin{array}{l}\text { Identify the reserves and intensify } \\
\text { the labour }\end{array}$ \\
\hline Goals & Receive maximum salary & Receive maximum income \\
\hline Motivation & $\begin{array}{l}\text { Salary, belonging to socially } \\
\text { protected group of the population }\end{array}$ & $\begin{array}{l}\text { Income, belonging to the middle } \\
\text { class }\end{array}$ \\
\hline The nature of labour & Consistency, uniformity & $\begin{array}{l}\text { Impulse rate based on order } \\
\text { conditions }\end{array}$ \\
\hline Extra efforts & Occasionally, as a last resort & $\begin{array}{l}\text { Depending on the state of the case } \\
\text { and his interest }\end{array}$ \\
\hline $\begin{array}{l}\text { Attitude toward colleagues, } \\
\text { subordinates }\end{array}$ & Follow instructions & Inspire the enthusiasm \\
\hline Developing the production & Divisive attitude & The desire to improve production \\
\hline Guarantees & Upper limit & Lower limit \\
\hline Control & Lower limit & Upper limit \\
\hline
\end{tabular}

Source: Own study.

Table 1 shows the divergence between the interests of the entrepreneur and the employees for all the items in the table. A mismatch of interests is natural for both the owner-entrepreneur and hired workers. If the entrepreneur as an owner of the assets of a small enterprise tends to ensure the stability and economic viability, employees are responsible to the owner only for the best use of provided resources. Thus, we can make the conclusion that there is the contradiction between owner's and employees' interests.

While studying the reasons for the mismatch of entrepreneur's and employee's interests, in our opinion, one should refer to such philosophical category as contradictions described by Hegel in detail. Contradictions, collision, and the struggle of opposites in his study are considered as the most common and deepest driving force of development. They are universal and objective: "Something moves, has momentum 
and activity," "only because ... has a contradiction in itself." That is, all development in the world can be considered as dividing the single entity into two opposites, "struggle" between opposites and softening or resolving these contradictions leads to a new impulse in development.

Every economic phenomenon, including small entrepreneurship, is controversial. The contradiction means such sides of the economic phenomenon, which are in inseparable unity, mutually exclude each other, penetrate each other. Economic contradictions explain objective internal "source" of economic phenomenon development without using external forces. They make it possible to understand the development of economic phenomenon as self-development.

The use of the system of contradictions makes it possible to carry out a deep analysis of social relations emerging in business, namely to reveal the content and causes of the economic contradiction between the owner-entrepreneur's interests and employees' interests. At the same time, it is necessary to consider the peculiarities of contradiction parties, their forms, social forces interested in their retaining and prompt reduction of the contradiction level.

Contradictions of interests between the owner-entrepreneur and employees and their relationship play a great role in the economic development, especially in the development of a small enterprise. The direction of energy of the owner-entrepreneur and hired worker depends on how these relations are oriented: to improving the social and psychological climate among the personnel of the enterprise, which contributes to strengthening the economic viability of the small enterprise, or to confrontation; to mitigating the economic contradiction of the owner-entrepreneur' interests and the employees' interests or to intensifying it.

It is necessary for the owner-entrepreneur to find a compromise solution ensuring the balance of his interests and the interests of his workers in order to prevent the deterioration of the socio-psychological climate among the personnel and the intensification of the contradictions. The decisions taken should not improve the position of the owner-entrepreneur by worsening the situation of hired workers, and vice versa.

It is necessary to strive for the most complete fulfillment of the following condition: what a person has contributed into the economy, into the social product, it should correspond to what he receives from the economy, otherwise, while distributing he will subsidize someone. At the same time, almost always a hired worker of a small enterprise contributes much more to the made product than he receives from the entrepreneur, that is, the employee subsidizes him.

The economic contradiction of the owner-entrepreneur's interests and the interests of hired workers arises, first, in goals of each party of the economic process. The goal of the owner-entrepreneur is to receive maximum income by any permitted and even 
sometimes prohibited ways, intensifying to the limit the work of hired workers. The main goal of the employee is to get a maximum salary that provides civilized living of the family and improving working conditions. In addition, not only "the policy" of the entrepreneur towards his employees but also the policy of the state reflected in the labour legislation could influence the existence and the level of this contradiction.

Conflicting interests of the owner and employees can lead to conflict situations. For example, if there is a lack of employee's social development, it will influence the efficiency of their work due to the low interests in the result that, in turn, will affect the development of the economic entities (that is especially crucial for small business). In this case, a significant part of the creative energy of the entrepreneur will be spent on overcoming the social tension among the personnel of his enterprise, and not on tactical issues regarding the activity or development of the business, which will also have negative consequences.

\section{Suggested Solutions/Recommendations}

It is necessary to develop assessment criteria and a set of indicators in order to identify the existence and to assess the level of social contradiction between the ownerentrepreneur's interests and employees' interests. Nowadays there are developed indicators of social responsibility characterizing, for example, the implementation of social programs by entrepreneurs: return on investment for charity; indicator of the efficiency of the charity program compared with the other non-charitable funds (promotion, advertisement, sales incentives) (Weiser and Zadek, 2000).

One can suggest the following criteria characterizing contradictions between the owner-entrepreneur's interests and the employees' interests:

$>$ mitigating the contradictions, i.e. the positive development of contradiction parties, for example, the entrepreneur increases the social responsibility to his employees;

$>$ intensifying the contradiction, i.e. the low level of entrepreneur's social responsibility that results in the negative influence of the contradiction on the results of business activity.

The degree of influence of the considered contradiction on the success of development of both the organization itself and the economy can be assessed, for example, by means of indicators characterizing the success of its work. These indicators can include indicators that indirectly reflect the "policy" of the state to mitigate this social contradiction. It should be noted that these indicators are more applicable to small enterprises. They can be dynamics of small business development reflected in the growth of number of small enterprises, several employees, a share of small enterprises that have become medium ones. 
Among the indicators that allow to assess the social responsibility of the entrepreneur and, accordingly, the level of contradiction between the owner-entrepreneur's and employees' interests within the enterprise there can be the following: the existence of social incentives for the employees improving their position as a worker, the level of staff turnover (or average work experience in the company), social reputation of the company (for example, whether there is a competition for jobs in the company).

Thus, we can say that the success (or failure) of business activity can be considered as one of the indicators of socio-economic contradictions between the ownerentrepreneur's interests and interests of hired workers. The more this contradiction is, the more it affects the success of the business. It is therefore necessary to identify the level of existing conflicts of interest in each enterprise and to form actions that will help to mitigate it.

\section{References:}

Carroll, A. 1999. Corporate social responsibility: Evolution of a definitional construct. Business \& Society, 38, 268-295.

Friedman, M. 1962. Capitalism and freedom. Chicago: University of Chicago Press.

Heald, M. 1957. Management's responsibility to society: The growth of an idea.

Heald, M. 1970. The social responsibilities of business: Company and community, 19001960. Cleveland, OH: Case Western Reserve University Press.

Holmes, S.L. 1976. Executive perceptions of corporate social responsibility. Business Horizons, 19, 34-40.

ISO. 2015. International standard ISO 26000 «Guidance on social responsibility». Available at: http://spbtpp.ru/wp- content/uploads/2015/11/law_national_standart.pdf.

Ivchenko, S.V. 2003. Evaluation of the impact of corporate social and charitable programs on the company's main activity indicators: review of foreign experience. Philanthropy in Russia: historical and socio-economic research, 2, 108-125.

Johnson, H.L. 1971. Business in contemporary society: Framework and issues. Belmont, CA: Wadsworth.

Jones, T. M. 1980. Corporate social responsibility revisited, redefined. California Management Review, 59-67.

Kreps, T.J. 1940. Measurement of the social performance of business. In An investigation of concentration of economic power for the temporary national economic committee (Monograph No. 7). Washington, DC, U.S. Government Printing Office.

Manne, H.G., Wallich, H.C. 1972. The modern corporation and social responsibility. Washington, DC, American Enterprise Institute for Public Policy Research.

Maslow, A.H. 1954. Motivation and personality. New York, Harper \& Row.

McGuire, J.W. 1963. Business and society. New York, McGraw-Hill.

Shevchuk, A.V. 2005. Social role of business in corporate governance models. SPERO. Social policy: assessment, recommendations, reviews, 2, 7-26.

Weiser, J., Zadek, S. 2000. Conversation with Disbelievers: Persuading Companies to Address Social Challengers. Ford Foundation, 56.

Nozick, R. 1974. Anarchy, State and Utopia. Oxford, Blackwell Publishers.

Rawls, J. 1999. A Theory of Justice. Revised Edition. Harvard University Press. 